\title{
Information Literacy and Digital Divide: The Case of the University of Botswana Students Studying Part-Time
}

\author{
Rose T. Kgosiemang ${ }^{1}$
}

\begin{abstract}
In Botswana, the costs and requirements to study full-time are very high. Not everyone can afford to study full-time without forfeiting their current roles, for example, in 1999 the Center for Continuing Education (CCE) in Botswana launched a Diploma in Primary Education distance education programme, to upgrade academic and professional qualifications of some 8000 primary certificate holders to diploma level. However, those teachers could not be released to attend courses in conventional institutions without compromising primary school work progress (Nage-Sibande, 2005: 250). Sometimes work and family life are core determinants to furthering education. Universities provide opportunities for students to choose their mode of learning as well as setting their pace of study. The University of Botswana (UB) like many other universities around the globe offers students the option to study and carry out other life commitments at the same time. This is in realization of the fact that learning part-time is a very important alternative and an opportunity for people to continue learning while they go on with their normal workloads and family or community responsibilities (Nage-Sibande, 2005). This paper will focus on students pursuing Part-time Diploma in Accounting and Business Studies programme (DABS) based at different geographical locations in the country. It is intended to discuss the plight of these students with regards to their lack of participation in the information literacy skills programme (ILS) offered to full-time undergraduate students as well as the inadequate access to both Information and Communication Technology and library resources. The paper will also discuss how their lack of access to ICT resources continues to widen the digital divide between those having access and those without access. Based on the authors' past participation in the teaching of ILS to DABS students it will discuss the pivotal role played by UB staff in the teaching of Information Literacy Skills (ILS) to DABS students as well as the collaborations and partnerships between librarians and other stakeholders such as the Extra Mural Unit of the Center for Continuing Education (CCE); Communication and Study Skills Unit (CSSU) and Computer Science which made it possible for Librarians to actively participate in the teaching of ILS. Further, the paper will discuss the problems experienced regarding issues of student support and access to and provision of resources, which are essential to the successful provision of courses taken by part-time students. Lastly, the paper will discuss efforts made by the CCE, North branch library, in Francistown, which is the outreach arm of the Department of Library Services at UB, in ensuring that library materials are provided to satellite centers outside Francistown through Technical Colleges, and the challenges experienced in the process.
\end{abstract}

Keywords: Part-time learners, librarians \& information literacy skills, ICT \& digital divide

\section{Introduction}

The Department of Library Services has been offering information literacy skills to year one students since 2002.The information literacy skills were offered under the umbrella of the General Education Courses. The GEC 121/122 were the two modules offered following a directive from the then Deputy Vice Chancellor, Academic Affairs. (DVC, AA) The DVC (AA further directed that the Computer and Information Skills courses should be developed within the framework of the General Education programme (Ojo, 2005). Among the students taught GEC 121/122 was the

\footnotetext{
${ }^{1}$ University of Botswana Library, Kgosiert [at] mopipi.ub.bw
} 
Diploma in Accounting and Business Studies students (DABS) students. The GEC 121/122 programme ran until 2010 after which a new improved programme, Communication and Academic literacy (COM) programme came into being, coordinated by Communication and Study Skills Unit of the Centre for Academic Development. The intention of the new programme was for information literacy skills to be embedded into the university curriculum. In terms of coverage the GECs 121/122 were offered to all new University of Botswana students regardless of their geographical location. What this means is that for purposes of teaching GECs 121/122 arrangements to teach DABS students were coordinated by the Extra-Mural Unit of the Centre for Continuing Education under the auspices of the Faculty of Business, university of Botswana. Staff had to apply (see the table below) and those who met the requirement set were scheduled to teach in either the Gaborone Centre or in other centres outside Gaborone such as Lobatse, Jwaneng, Mahalapye, Selibe-Phikwe, Maun and Francistown where DABS students were located.

\section{Information Literacy}

Information literacy is defined by Andretta (2005:15) as the ability to identify the need for information, know the importance of accurate and authentic information; develop search strategies to assist in finding information; source information; evaluate; use and organize information effectively. Rader (2002) defines information literacy as skills needed by all citizens to be successful in the information environment of the twenty first century. According to the Alexandria Proclamation of 2005 cited by Catts and Lau (2008) information literacy (IL) is considered essential for individuals to achieve personal, social, occupational and educational goals. Further, Catts and Lau (2008) state that IL skills are necessary for people to be effective lifelong learners and to contribute in knowledge societies.

The following are IL elements that are consistent with the definition of IL developed for use in higher education and argued by Campbell (2004:9):

a) Recognise information needs

b) Locate and evaluate the quality of information

c) Store and retrieve information

d) Make effective and ethical use of information, and apply information to create and communicate knowledge (Campbell, $2004: 11)$

Regarding these elements one has to :

i. Be aware that they require information to solve problems in all spheres of life

ii. Be aware that the skill required to locate information will depend on the context a person is applying their IL skills. In the case of DABS students for example, the IL skills are required to locate information for assignments, projects, etc.

iii. Have the skills required to locate information.

iv. Be able to store and retrieve information

v. Have the capacity to recognise information needs as well as make effective and 
ethical use of information, and apply information to create and communicate knowledge (Campbell, 2004:11).

The above elements together with the following competencies according to Rader (2002:141):

a) The ability to determine the nature and extent of the information needed;

b) The ability to assess needed information effectively and efficiently;

c) The ability to evaluate information and its sources critically and to incorporate selected information into one's knowledge base

d) The ability to understand many of the economic, legal and social issues surrounding the use of information;

e) The ability to access and use information ethically and legally.

do not only convey similar sentiments about the critical nature of IL skill but they also show that the concept has been widely documented by scholars .It is therefore critical to come up with solutions that will demonstrate to what extent the concept has adequately been understood by all.

\section{Digital Divide}

Digital divide as defined by the United Nations Education, Scientific and Cultural Organization (UNESCO, 2000) is a phenomenon that results from the unequal application of, and access to, information and communication technologies leading to a global gap between information 'haves' and 'have nots'. Cullen (2001) defines digital divide as a gap that exists in most countries between those with access to tools of information and communication technologies and the knowledge that they provide access to and those without such access to skills. He notes that this may be due to socio-economic factors or it may be physical disabilities.) Naidoo and Raju (2012) who have adopted Cullen $(2001: 311)$ definition refer to digital divide as the gap that exists between those with ready access to information and communication technology (ICT) tools and those without such as skills to enable access. Of the four interpretations provided by Fink and Kenny (2003) there is one that refers to a gap in the ability to use ICTs measured by the skills base and the presence of numerous complementary assets. Campbell (2001:1) states that digital divide refers to situations in which access is a marked gap in access to or use of ICT devices. Compaine (2001) on the other hand define digital divide as the perceived gap between those who have access to the latest information technologies and those who do not whereas Bolt and Crawford (2000:39 cited by Ersoy and Guneyli (2016) define digital divide as the gap created by the lack of access to and the manner of use of technology by members of various social identity groups .

For purpose of this paper and its focus on students studying part time the digital divide definition that best describes the DABS situation is the one that makes a distinction between people who do and those who do not have internet access. This paper will focus on the digital divide that result from lack of access to ICT resources and the lack of information literacy training offered by the University of Botswana librarians. 
Kgosiemang (2016). Education Reform Journal, 2016, 1(2), 56-70

\section{Background of Information Literacy at the University of Botswana}

The University of Botswana has accepted IL as a lifelong learning skill. UB Library is the only academic library in Botswana that has been offering information literacy skills since 2002. Prior to that year UB Library used to offer bibliographic instruction to both undergraduate students doing research and also to postgraduate research students. Although bibliographic instruction was not wholly adopted by all faculties it had its merits in faculties that adopted it. There was collaboration between academic staff and librarians who offered it and there were some benefits derived from the instruction by students at that time. IL skills programme at the University of Botswana library was offered as part of the General Education Course from 2002 to 2010. The end of 2010 marked the end of IL skills

Programme being offered as a stand- alone module but is now offered as part of the Communication and Academic Literacy (COM) programme coordinated by the Communication and Study Skills (CSSU) unit of the Centre of Academic Development (CAD). Limited IL skills among library professionals in other Tertiary institutions and poor internet connectivity in some parts of Botswana are some of the constraints delaying full adoption and implementation of IL teaching. The author of this paper while serving on a committee known as the Unified Board of Affiliation Institutions between 2012 and 2016 had the opportunity to assess libraries in institutions affiliated to the University of Botswana. Most of those libraries are still behind where the teaching of information literacy is concerned. With regards to the sister universities, the Botswana University of Science and Technology (BUIST) and the Botswana University of Agriculture and Nature (BUAN) and other tertiary institutions in the country their IL status is not known. The University of Botswana library has made huge strides in terms of ILS programme development and skilled human resources.

\section{Purpose of the Study}

The general purpose of this paper was to investigate factors leading to the exclusion of DABS students in the teaching of information literacy skills with the aim of advocating for their inclusion in the information age

Specifically the study seeks to:

1. To create awareness among library professionals of their role in bridging the digital divide

2. To remind librarians of their critical role in advocacy as a tool that could be adopted to speak and argue on behalf of part-time students and other communities they serve with the view to improving the lives of such students and communities. Brey- Cassiano (2008) opines that advocacy is important whether you want to gain support for a new library facility or you want to increase your library's overall budget. The author further posits that when thinking about advocacy it is important to know what you want to accomplish through your advocacy campaign. 
3. To suggest alternative approaches that can be adopted by the Department of library Services in addressing issues affecting part-time students with the view of narrowing the divide that already exists between full-time and part-time students

\section{Review of the literature}

Research on information literacy clearly shows how essential the skills are for all students. The skills are even more critical for adult and part-time learners, especially those unfamiliar with information systems. The critical role of libraries and librarians in bridging the digital divides is widely documented. Though there are several perspectives regarding the phenomenon there is evidence that libraries have a role to play in bridging the gap between the advantaged and disadvantaged. Kranich (2001) also indicates that librarians have a unique role in leveling the playing field and bridging the widening gap between the information haves and have-nots. Further, she notes that libraries are more essential to the economic wellbeing of their communities, to the advancement of learning, to coping with information overload and to closing the digital divide (Kranich,2001). The important role of the library in student learning is also heralded by (Ojedokun, 2007); (Anunobi, 2013), (Naidoo and Raju, 2011.)

Zhao, Kim, Suh and Du (2007) are of the view that both ICT and the internet allows for the implementation of a wide range of services that have changed the way we interact, communicate, do business or even the way politics are conducted while Cullen (2001) :on the other hand opines that the internet is not in itself an education; neither does it teach literacy. Further, he states that the internet requires highly developed skills to access and interpret information found (Cullen, 2001 : 312). Further, he is of the view that the internet should include access to the more valuable information sources, indexes, full-time databases and journals that are not freely available on the internet leaving researchers in developing countries excluded from knowledge that may be valuable in their subject areas (Cullen, 2001: 311). This is where library professionals come in. They are key to the successful and effective use of ICT through their teaching of information literacy skills. Kranich (2001) states that libraries do not only offer access to computers and networks, but also the content, training and expertise crucial to ensure widespread participation in information society. On the issue of academic institutions playing significant roles, Anunobi (2013) asserts that the university library plays a significant role in university education through its function or processing and dissemination of information. This paper is concerned with the role that the University of Botswana library plays with regards to attempting to narrow the divide between students studying full-time and those studying part-time. In approaching this topic I will consider who DABS students are, where they are located and what role the University of Botswana is playing in ensuring their access to information literacy skills and information and communication technologies

\section{Methodology}

This study has relied heavily on observation as a tool for data collection. Information was collected from reports presenting library usage statics. This assisted in investigating library usage by students studying part-time. Experience as a librarian teaching information literacy to DABS 
students between 2002 and 2012 was also used to determine ways in which students with access to computers, and information literacy skills coped as compared to those without both computer and ILS background. The author also had an opportunity to communicate through electronic mail with some Coordinators of DABS centres as well as some Library professionals in Francistown and the Okavango Research Institute (ORI) regarding DABS students' access to the internet, Wi-Fi, information literacy and ICT skills. The other data collection method involved desk research. The information collected clearly indicated the extent to which the divide was widening among students studying part-time

\section{Background on DABS Programme and Services Provided for Them}

The Diploma in Accounting and Business Studies (DABS) programme runs on part-time basis in the evenings by the Extra-Mural Unit (EMU) of the Centre for Continuing Education (CCE) under the auspices of the Faculty of Business, University of Botswana (Department of ExtraMural and Public Education handbook, 2007-2008). DABS students are studying part-time in the evenings. In terms of where they are located, there are seven (7) centres where DABS students are located. These are Gaborone, Lobatse, Jwaneng, Mahalapye, Selibe-Phikwe, Francistown and Maun. With regards to how they are being provided for by the University of Botswana Library, there are a number satellite centres through which students were provided for facilitated by a Memorandum of Agreement between the University of Botswana and Botswana Government. In an attempt to give an account of how they used to be provided for the following details will be used:

$>$ Teaching of information literacy employed on a part-time basis by the Gaborone Centre for Continuing Education

$>$ Provision of library resources through a Memorandum of Agreement between the University of Botswana and the Botswana Government (Expired 2007)

\section{Information Literacy for DABS Students}

All part-time lectures including librarians who offered information literacy skills courses were required to apply to the Centre for Continuing Education. If they qualified they were employed for a full academic year. The teaching was done in the evenings and over the week-ends. During practical sessions Library professionals always partnered with Information Technology lecturers who attended to all IT related queries and ensured that computer facilities were functioning well. Library professional would then deliver both GEC 121/122 modules. GEC 121 modules covered theory whereas GEC 122 covered both theory and practical sessions where students were introduced to online and networked databases; Legal issues of Information and different citation styles. Library staff were involved in the teaching of DABS students from 2002 until 2012.

\section{Mini Study Carried Out and Findings}

In an effort to find out what the situation was like following the discontinuation of the 
teaching of GEC 121/122, a mini study was carried out. The study involved charting with DABS Centre Coordinators; sharing with them on issues regarding the teaching of ILS in the past and wondering how things were going following the discontinued participation by library professionals.

The Table 1 below is a result of what was found out.

Table 1. Status of ILS \& Access to ICT by DABS Students

\begin{tabular}{|c|c|c|c|c|c|}
\hline $\begin{array}{l}\text { DABS } \\
\text { Centre }\end{array}$ & $\begin{array}{l}\text { No. of } \\
\text { Students }\end{array}$ & $\begin{array}{l}\text { Mode of } \\
\text { Communication }\end{array}$ & $\begin{array}{l}\text { Access to } \\
\text { ICT }\end{array}$ & $\begin{array}{l}\text { Teaching of } \\
\text { ILS }\end{array}$ & Access to Library resources \\
\hline Maun & $\begin{array}{l}\text { About } \\
25\end{array}$ & $\begin{array}{l}\text { Through sms and } \\
\text { what's up which } \\
\text { are costly for both } \\
\text { the Coordinator } \\
\text { and students }\end{array}$ & & & $\begin{array}{l}\text { Had access to Maun T. C. Library } \\
\text { * Library under-resourced due to } \\
\text { expiration of MOA } \\
\text { * Library collection and computers } \\
\text { available at ORI } \\
\text { * Opening hours not conducive for } \\
\text { access into the library by DABS since } \\
\text { they are working. } \\
\text { * Library operates normal working } \\
\text { hours } 0745-4.30 \text { p.m... Does not open } \\
\text { during week-ends } \\
\text { * MTC and Maun Brigades open } \\
0800-1630 \text { Mondays-Fridays } \\
* \text { Library closes between } 1300 \text { and } \\
1400 \text { during week days DABS } \\
\text { students attend lessons from 1730- } \\
2000\end{array}$ \\
\hline Mahalapye & $\begin{array}{l}\text { About } \\
15\end{array}$ & $\begin{array}{l}\text { * Use e-mail all the } \\
\text { time. } \\
\text { * Since most of } \\
\text { them are working } \\
\text { they access e-mail } \\
\text { at work. } \\
\text { Sms was best but } \\
\text { needed loads of } \\
\text { airtime. What's up } \\
\text { was another option } \\
\text { for communicating } \\
\text { with students, but } \\
\text { not all students own } \\
\text { smart phones. }\end{array}$ & $\begin{array}{l}\text { Students have } \\
\text { access to } \\
\text { computers } \\
\text { during ICT lab } \\
\text { sessions. } \\
\text { Otherwise } \\
\text { students use } \\
\text { ordinary } \\
\text { classrooms with } \\
\text { chalk boards }\end{array}$ & & $\begin{array}{l}\text { Students used to attend classes at } \\
\text { Madiba Secondary School. Attempts } \\
\text { also were made to send book to Madiba } \\
\text { Secondary School to be accessed by } \\
\text { students }\end{array}$ \\
\hline $\begin{array}{l}\text { Selibe } \\
\text { Phikwe }\end{array}$ & $\begin{array}{l}\text { About } \\
15\end{array}$ & $\begin{array}{l}\text { Both students and } \\
\text { lecturers use their } \\
\text { airtime } \\
\text { communicate with } \\
\text { each other. Noted } \\
\text { that it was costly for } \\
\text { both parties. } \\
\text { Created What's up } \\
\text { group for both } \\
\text { students and } \\
\text { lecturers }\end{array}$ & $\begin{array}{l}\text { Students have } \\
\text { access to } \\
\text { computers } \\
\text { during lab } \\
\text { sessions. } \\
\text { Student's } \\
\text { registration } \\
\text { and } \\
\text { introduction to } \\
\text { use of } \\
\text { computers } \\
\text { done by the } \\
\text { ICT lecturer. }\end{array}$ & $\begin{array}{l}\text { Never had a } \\
\text { Librarian } \\
\text { who } \\
\text { ught ta } \\
\text { students ILS }\end{array}$ & $\begin{array}{l}\text { Students use the Public library. Attempt } \\
\text { was made by the Librarian to send } \\
\text { books to Selibe Phikwe Technical } \\
\text { College for use by DABS students but } \\
\text { were turned down due to the expired } \\
\text { MOA. }\end{array}$ \\
\hline
\end{tabular}




\section{CCE North Francistown Branch Library}

Opening hours

At CCE North Branch Library, opening hours were changed by Library Management on several occasions. Initially the library operated normal working hours. Attempts were made to adjust them as follows : 0745-16.30; 09.00-17.45 and 12.45-21.00 hours. The hours were adjusted again in August 2008 as follows : 0745-18.00 Monday to Thursday and Friday 0745-16.30. The library does not open week-ends.

\section{Findings}

$>$ Heavy reliance on social media which is constrained by its cost

$>$ Library opening hours which are not only restrictive but are also not conducive to learning by students studying part time.

$>$ Most students are working full time and cannot access the Library over the week-ends

$>$ Lack of access to computer facilities due to restrictive library opening hours

$>$ Lack of ILS skills in most centres since the discontinuation of the teaching of information literacy skills by Library professionals in 2012

$>$ Lack of access to the internet which is available in some Technical Colleges and the Okavango Research Institute in Maun which also close at 16.30 hours when students knock off from their work

$>$ Poor internet connectivity and low network coverage in some areas outside Gaborone are some of the challenges facing educational institutions in Botswana

$>$ Intermittent power cuts due to load shedding which affect internet supply

Clearly the table shows that DABS students are deprived of IL skills that are key to active participation in information society. Students' access to ICT skills are only limited to their laboratory training. Lack of access to electronic databases that the library subscribes to in support of the learning and research has also been noted.

The practical implications of the findings are central to the core of IL and ICT as they relate to the acquisitions of skills needed by DABS students especially since they are on their own and need to fend for themselves.

\section{The Role of the University of Botswana Library in Bridging the Digital Divide}

One of the values of the University of Botswana that is enshrined in the Strategy, a Strategy for Excellence : the University of Botswana's Strategic Plan to 2016 and Beyond, 2008 : 5) is equity by ensuring equal opportunity and non-discrimination on the basis of personal, ethnic, religious, gender or other social characters. It is this lack of equity in the treatment of students studying parttime that is of concern. Lack of equity in access to resources that is reflected by fewer library 
opening hours at CCE North branch library and Maun Technical College as compared to the University of Botswana main Library which opens 0745-1100 p.m. Mondays to Thursdays and 10.00 a.m. -4.00 p.m. on Saturdays; 10.00 a.m. - 1000 on Sundays when the academic year is in session whereas CCE North opens Mondays to Thursdays 0745-6.00 p.m.; lack of equity in the provision of ICT facilities at CCE North branch library; lack of equity in the provision of information literacy skills that would enable DABS to meaningfully and successfully use ICT resources the same way the University of Botswana first year full time students go through Information Literacy Skills training as part of the Communication and Academic Literacy at the beginning of every academic year. As indicated above the CCE North Branch Library and the Maun Technical College which have library buildings are the only institutions that are dedicated for serving the DABS students but their opening hours are not conducive to DABS learning in the sense that they close as early as 4.30 p.m. and 6.00 p.m. Not only does access to the library afford students the opportunity to use the collections and other resources, it also gives them the opportunity to interact with staff, to learn how to use these resources and to be empowered with the necessary information and communication technology skills. This is supported by Aqili and Moghaddam (2008 : 229) who are of the view that librarians have a responsibility to train their patrons in modern retrieval strategies; particularly in the use of the internet, World Wide Web, electronic databases so that they are able to access information, communication and technologies. By so doing they will be bridging the digital divide.

\section{Conclusion}

There is no doubt that Information is a primary good that everybody needs in order to function effectively. However, people also need the social and cultural 'capital' to use information appropriately, namely, the skills to select and process information and to use it in one's social position and networks (Bornman, Elirea (2016). The review of the literature has shown the critical role of the library in bridging the digital divide both as the place where access to ICT is assured and also as a place where there are information professionals trained in enabling people access, select, evaluate and use it effectively. Van Dijk, (2007), cited by Bornman (2016) is of the view that in an information society, information is regarded as a primary good that everybody needs in order to function effectively. This statement does not only support what has been said by Bornman (2016) it affirms the view that information professionals have a role to play in bridging the digital divide.

This paper has discussed the role played by ICT, libraries and library professionals in bridging the divide. The paper has also talked about DABS and their situation at various centres coordinated by part-time lecturers or computer personnel. It has also discussed the involvement of library professionals in the teaching of information literacy skills between 2002 and 2012 during which Dr Gangappa Kuruba was the Head Coordinator in the Extra-Mural \& Public Education Department. Lastly, the author attempted to present some of the challenges faced by students learning part-time . 
Kgosiemang (2016). Education Reform Journal, 2016, 1(2), 56-70

Recommendations

$>$ University of Botswana library (UBL) should enable and empower all bonafide students with IL skills to be critical and independent learners

$>$ UBL should adopt and promote IL as a key component for lifelong learning

$>$ All new students should be grounded in the same basic IL and ICT skills in order to be able to apply the skills in their learning

$>$ UB Library should consider developing policies that advocate for the bridging of the digital divide through the provision of life-long learning skills and universal access to ICT.

$>$ Library management should advocate for the renewal of the Memorandum of Agreement between the University of Botswana and the Ministry of Education. It is key to access to information and computer facilities by students located centres where DABS students are located.

The implications based on results of the study for potential education reforms:

Botswana is committed to lifelong learning and like many countries globally it is constantly reforming its education to be in line with the ever changing socioeconomic situation. The 1994 Revised National Policy on Education (RNPE) was one such effort based on the report of the National Commission on Education 1992/93 established by the president to review Botswana's education system since 1977 (Maruatona, 2011: 125). Among its objectives were the adult learning objectives geared towards ensuring basic education, further education and training that are relevant and available to a larger number of people and for lifelong education to be provided to all sections of the population among which there are part-time learners. (Maruatona, 2011: 125). This clearly shows the extent to which Government of Botswana is committed to inclusive education.

The paper has raised serious issues of inequalities of access to information and ICT resources; social divide between groups due to digital divide. Such issues seriously impact on students' ability to apply the information literacy skills in a digital environment. The lack of access to ICT skills does not only deny part-time learners the opportunity to partake on the knowledge economy due to their lack of the requisite skills but also frustrates efforts by Botswana Government through its education reforms, education policy reviews and other efforts as stated in the country's 2016 Vision which aimed to put the country on an equal footing with other nations (Vision 2016). The Government of Botswana has since the 1970s been aware of the equity issues of education hence the several reforms mentioned above. (Siphambe, 2000), reforms that are meant to empower students with appropriate skills as well as develop in them attributes such as creativity, versatility, innovations, critical thinking and problem solving skills (Tabulawa, 2009).Clearly not every Motswana student can afford to compete at same levels of 
Kgosiemang (2016). Education Reform Journal, 2016, 1(2), 56-70

education with others due to financial constraints. However, that should not be used against students learning part-time by applying restrictive measures that deny them access to resources and services. Such as unconducive library opening hours The knowledge that education is a fundamental human right should prevail.

\section{References}

ALA (American Library Association). (1989). A progress report on information literacy : an update on the ALA Presidential Committee on Information Literacy. Washington, DC, 10 January 1989. http://www.ala.org/ala/acrl/acrlpubs/whitepapers/presidential.htm

Alexandria Proclamation (2005). http://archive.ifla.org

Andretta, S (2005). Information literacy : a practitioner's guide. Oxford : Chandos Publishing.

Anunobi, C. Y. (2013). Human capacity building in Nigerian University libraries : an imperative for academic libraries' contribution towards national development. African Journal of Library, Archives \& Information Science 23(1) : 33-44

Aqili, S. V. and Moghaddam, A. I. (2008). Bridging the digital divide : the role of libraries and information professionals in the third millennium. Electronic Library, 26(2) : 226-237

Bancroft, J. (2016). Multiliteracy centres spanning the digital divide; providing a full spectrum of support. Computer and Composition, $41: 46-55$.

Bornman, E. (2012). The mobile phone in Africa : has it become a highway to the information society or not? Contemporary Educational Technology, 3(4) : 278-292.

Bornman, E. (2016). Information society and digital divide in South Africa : results of longitudinal surveys. Information Communication and Society. 19(2) : 264-278

Brey-Casiano, C. A. (2008). Library advocacy in a world community. In : Walter, C. and Gerda, M. (2008) Thinking outside the borders : library leadership in a world community : a manual for professional development, Urbana Champaign, ILL. : Mortenson Center for International Library Programs at the University of Illinois. http://www.library,oiuc.edu/mortenson/book

Cambpell, D. (2001). Can the digital divide be contained? The digital divide : employment and development implications. International Labour Review. 140(2) : 119-142.

Catts, R. and Lau, J. (2008). Towards information literacy indicators : conceptual framework. Paris : United Nations Educational, Scientific, Cultural Organisation (UNESCO).

Chowdhury, N. (2000). Information and communication technologies and IF PRI's mandate : a conceptual framework. Washington D. C. : International Food Policy Research Institute 
Kgosiemang (2016). Education Reform Journal, 2016, 1(2), 56-70

Cullen, R. (2001). Addressing the digital divide. Online Information Review. 25(5) : 311-320.

Cullen, R. (2003). The digital divide : a global and national call to action. The Electronic Library, 21(3) : 247-257.

DiMaggio, P. and Hargittai, E. (2001). From the digital divide to digital inequality : studying internet use as a penetration increases. Center for Arts and Cultural Policy Studies, Working Paper 15.

Dutch, M. and Muddiman, D. (2001). The public library, social exclusion and the information society in the United Kingdom. Libri, $51: 183-194$

Echezona, R. I. and Ugwuanyi, C. R. (2010). African University Libraries and internet connectivity : challenges and way forward. Library Philosophy and Practice: 1-13.

Ersoy, M. and Guneyli, A. (2016). Social networking as a tool for lifelong learning with Orthopedically Impaired Learners. Journal of Educational Technology \& Society,19 (1) : 4152.

Huang, J. and Russell, S. (2006). The digital divide and academic achievement. The Electronic Library, 24(2) : 160-173. Kranich, Nancy (2001). Libraries :ensuring information equity in digital age. American Libraries, 32(1): 1

Kvasny, L. and Kell, M. C. (2006). The challenges of redressing the digital divide : a tale of two US cities. Information Systems Journal, 16 (1) : 23-53.

Maruatona, T. (2011). Lifelong learning and the pursuit of a vision for sustainable development in Botswana. Studies in Continuing Education, 33(2) : 121-138.

Nage-Sibande, B. (2005). Development of distance education in Botswana. The Quarterly Review of Distance Education, 6(3) : 243- 252.

Naidoo, S. , Raju, J. (2012) Impact of the digital divide on information literacy training in a higher education context. South African Journal of Libraries \& Information Science 78(1) : 3444.

Ofua, O. J. and Emiri, O. T. (2011). The role of public libraries in bridging the digital divide, chapter 14, International Journal of Digital Library Systems, 2(3) : 14-22

Ojedokun, A. A. (2007). Information literacy for tertiary education students in Africa. Ibadan : Third World Information Services.

Ojo, S. O., [et al], (Ed.). (2005). Computing and Information Skills Fundamentals II : lecture notes series. Gaborone : Department of Computer Science, University of Botswana.

Owusu-Asah, E. K. (2003). Information Literacy and the academic library : a critical look at a concept and controversies surrounding it. The Journal of Academic Librarianship. 29 (4). :219- 
Kgosiemang (2016). Education Reform Journal, 2016, 1(2), 56-70

230.

Rader, H. B. (2002). Teaching and assessing information literacy skills in the twenty first century : a global perspective. Library trends. 51(2) : 141-261.

Rainie, L. (2001). The state of digital divides. Pew : Research Internet Project. Retrieved from : http://www.pewinternet.org

Rapchak, M. E. , Lewis, L. A, Motyka, J. K. and Balmert, M. (2015). Adult Learning. 26(2) : 135-142). Sturges, P., Gastinger, A. (2010). Information literacy as a human right. Libri, 60 (3):195-202.

Sipambe, H. K. (2000). Rates of return to education in Botswana. Economies of Education Review, 19 : 291-300.

Bornman, E. (2012). The mobile phone in Africa : has it become a highway to the information society or not? Contemporary Educational Technology, 3(4) : 278-292.

Bornman, E. (2016). Information society and digital divide in South Africa : results of longitudinal surveys. Information Communication and Society. 19(2) : 264-278

Brey-Casiano, C. A. (2008). Library advocacy in a world community. In : Walter, C. and Gerda, M. (2008) Thinking outside the borders : library leadership in a world community : a manual for professional development, Urbana Champaign, ILL. : Mortenson Center for International Library Programs at the University of Illinois. http://www.library,oiuc.edu/mortenson/book

Cambpell, D. (2001). Can the digital divide be contained? The digital divide : employment and development implications. International Labour Review. 140(2) : 119-142.

Catts, R. and Lau, J. (2008). Towards information literacy indicators : conceptual framework. Paris : United Nations Educational, Scientific, Cultural Organisation (UNESCO).

Chowdhury, N. (2000). Information and communication technologies and IF PRI's mandate : a conceptual framework. Washington D. C. : International Food Policy Research Institute

Cullen, R. (2001). Addressing the digital divide. Online Information Review. 25(5) : 311-320.

Cullen, R. (2003). The digital divide : a global and national call to action. The Electronic Library, 21(3) : 247-257.

DiMaggio, P. and Hargittai, E. (2001). From the digital divide to digital inequality : studying internet use as a penetration increases. Center for Arts and Cultural Policy Studies, Working Paper 15.

Dutch, M. and Muddiman, D. (2001). The public library, social exclusion and the information society in the United Kingdom. Libri, $51: 183-194$ 
Kgosiemang (2016). Education Reform Journal, 2016, 1(2), 56-70

Echezona, R. I. and Ugwuanyi, C. R. (2010). African University Libraries and internet connectivity : challenges and way forward. Library Philosophy and Practice: 1-13.

Ersoy, M. and Guneyli, A. (2016). Social networking as a tool for lifelong learning with Orthopedically Impaired Learners. Journal of Educational Technology \& Society,19 (1) : 4152.

Huang, J. and Russell, S. (2006). The digital divide and academic achievement. The Electronic Library, 24(2) : 160-173. Kranich, Nancy (2001). Libraries : ensuring information equity in digital age. American Libraries, 32(1): 1

Kvasny, L. and Kell, M. C. (2006). The challenges of redressing the digital divide : a tale of two US cities. Information Systems Journal, 16 (1) : 23-53.

Maruatona, T. (2011). Lifelong learning and the pursuit of a vision for sustainable development in Botswana. Studies in Continuing Education, 33(2) : 121-138.

Nage-Sibande, B. (2005). Development of distance education in Botswana. The Quarterly Review of Distance Education, 6(3) : 243- 252.

Naidoo, S. , Raju, J. (2012) Impact of the digital divide on information literacy training in a higher education context. South African Journal of Libraries \& Information Science 78(1) : 3444.

Ofua, O. J. and Emiri, O. T. (2011). The role of public libraries in bridging the digital divide, chapter 14, International Journal of Digital Library Systems, 2(3) : 14-22

Ojedokun, A. A. (2007). Information literacy for tertiary education students in Africa. Ibadan : Third World Information Services.

Ojo, S. O., [et al], (Ed.). (2005). Computing and Information Skills Fundamentals II : lecture notes series. Gaborone : Department of Computer Science, University of Botswana.

Owusu-Asah, E. K. (2003). Information Literacy and the academic library : a critical look at a concept and controversies surrounding it. The Journal of Academic Librarianship. 29 (4). : 219-230.

Rader, H. B. (2002). Teaching and assessing information literacy skills in the twenty first century : a global perspective. Library trends. 51(2) : 141-261.

Rainie, L. (2001). The state of digital divides. Pew : Research Internet Project. Retrieved from: http://www.pewinternet.org

Rapchak, M. E. , Lewis, L. A, Motyka, J. K. and Balmert, M. (2015). Adult Learning. 26(2) : 135-142). Sturges, P., Gastinger, A. (2010). Information literacy as a human right. Libri, 60 (3): 195-202. 
Kgosiemang (2016). Education Reform Journal, 2016, 1(2), 56-70

Sipambe, H. K. (2000). Rates of return to education in Botswana. Economies of Education Review, $19: 291-300$.

Tabulawa, R.T. (2009). Education reform in Botswana : reflections on policy contradictions and paradoxes. Comparative Education, 45 (1) : 87-107.

United Nations Education, Scientific and Cultural Organization (UNESCO, 2000). Role of public libraries in bridging the digital divide. International Journal of Digital Library Systems, 2(3) : $14-22$

Universal Declaration of Human Rights (1948).

University of Botswana. Centre for Continuing Education. (2007). Memorandum of Agreement between the University of Botswana and Ministry of Education on Collaboration of Technical College Resources.

University of Botswana. (2008). A Strategy for Excellence : University of Botswana Strategic Plan to 2016 and Beyond. University of Botswana. Faculty of Business (2007-2008). Department of Extra-Mural and Public Education handbook. World Bank (2002). World Development indicators, Washington D. C. : World Bank

Vision 2016. (1997). Towards prosperity for all : a summary. Gaborone.: Presidential Task Group for Long Term Vision For Botswana 